\title{
Using stories to engage students in a health education school program about genetic testing
}

\author{
Eleftheria Papadeli ${ }^{*}$, Eleni Tsakiridou² and Evangelia Mavrikaki ${ }^{3}$ \\ ${ }^{1}$ Laboratory Centre of Physical Sciences, Kozani, Greece \\ 2 Department of Primary School Education, University of Western Macedonia, Greece \\ ${ }^{3}$ Department of Primary School Education, National Kapodistrian University of Athens, Greece \\ For correspondence: eripapadeli@gmail.com
}

\begin{abstract}
:
The health education program entitled "Show me your genes and I will tell you who you are" was implemented in a Junior High School in Greece in order to help the participating students get acquainted with basic genetics concepts as well as the procedures and implications of genetic testing. This article presents the stories that were used in one of the sessions of the program and the conclusions that were drawn from their use.
\end{abstract}

Keywords: Health education, genetic diagnosis.

\section{Introduction}

It is common knowledge that the contemporary applications of genetics and biotechnology, such us genetic diagnosis, genetic engineering, cloning, gene therapy etc, have an enormous impact on society, since, apart from advantages, they have significant ethical, legal and social implications. The evaluation of the above requires scientifically literate individuals (Driver et al., 2000).

Indeed, scientific literacy has been a major goal of education in the physical sciences globally. According to the National Research Council (1996), the scientifically literate individual possesses the knowledge and understanding of scientific concepts and processes that are necessary for making informed decisions on personal and societal issues.

One of the major applications of genetics with conflicting reviews is genetic diagnosis. Genetic diagnosis, in general, can provide individuals with information regarding predisposition to several genetic diseases, can offer diagnosis to individuals who are already experiencing symptoms or can indentify carriers of a genetic disease, thereby contributing in estimating the risk of transmitting a genetic disorder to their offspring. However, apart from genetic diagnosis in adults, diagnosis can be made in fetuses prenatally (prenatal diagnosis), thus offering the parents the option of terminating an already established pregnancy (Cockell \& Rodeck, 2001). There is also the possibility of diagnosing a genetic disease before a pregnancy has been established (preimplantation genetic diagnosis), by testing of embryos that have been obtained with in vitro fertilization prior to cell differentiation and implantation and selecting only the unaffected one/ones for transfer to the uterus (Handyside \& Delhanty, 1997). In that sense, preimplantation genetic diagnosis is an alternative to prenatal diagnosis for patients at risk of transmitting an inherited disease to their offspring, thus eliminating the need of terminating an affected pregnancy (Harper \& Bui, 2002).

Especially, after the completion of the sequencing of the human genome in 2003 and the development of methods for screening genetic anomalies, genetic diagnosis has been a favourite subject in the mass media as well as the movies. Nonetheless, it seems that the society is not well-informed in issues 
associated with genetic diagnosis and, consequently, the majority of the candidates who undergo genetic diagnosis have minimal or very little knowledge of basic biological concepts and procedures necessary to understand the information given to them during the genetic consultancy procedure as well as the implications involved, a fact that may hinder an autonomous, fully-informed decision (Decruyenaere, 1995). As a result, it is necessary for the students, who are the "future adults and possible users of genetic tests", after their graduation from compulsory education, to have basic genetic knowledge in order to develop critical thinking abilities and be able to think over the usefulness of genetic diagnosis as well as the ethical, legal and social issues that are involved with its application (Decruyenaere, 1995).

\section{The program}

In order to engage $9^{\text {th }}$ grade students of a public junior high school in Greece in socio-scientific issues involved in genetic testing, a health education program entitled "Show me your genes and I will tell you who you are" was designed by the authors and implemented by one of them - called the instructor from now on - during the school year 2015-2016. Health education programs in Greece are non-compulsory educational programs that take place after school and aim to increase the students' awareness on a specific health issue.

The primary goal of the program was the familiarization of the students with basic genetics concepts and their acquaintance with the procedures and the implications of genetic testing, so that, as future citizens, they will be in the position to take a stand towards ethical dilemmas brought over by the advances in biology and medicine and take informed decisions about certain issues. The program took place from December 2015 until May 2016 and included 15 weekly sessions, which are summarized in Table 1. Each session lasted for 2 hours.

Table 1. The weekly sessions of the program.

\begin{tabular}{|c|c|}
\hline Week & Activities \\
\hline \multirow[t]{4}{*}{1} & Creation of a cooperative working environment \\
\hline & Division in 8 teams \\
\hline & Formation of a pedagogic contract \\
\hline & Pre-questionnaire \\
\hline 2 & DNA isolation \& Chromosome observation \\
\hline 3-5 & Film GATTACA \& discussion in class \\
\hline 6 & Discussion on genetic testing in adults for medical reasons \\
\hline 7 & Discussion on prenatal diagnosis, preimplantation diagnosis and choice of characteristics \\
\hline 8 & Role-plays \\
\hline 9 & Stories-Case studies \\
\hline 10 & “The DNA detective game" \\
\hline 11 & Teleconference with a representative from the National Bioethics Committee \\
\hline \multirow[t]{6}{*}{12} & Role distribution \\
\hline & Searching, processing \& editing of material (teams 1-6) \\
\hline & Creation, distribution \& processing of questionnaires (team 7) \\
\hline & Scenario writing and shooting of short film ("CSI Kozani: Murder in the lab") (team 8) \\
\hline & "DNA Song" writing \& video-clip making (team 8) \\
\hline & Creation of artifacts for the World DNA Day from single students \\
\hline 13 & Participation in the $2^{\text {nd }}$ Health Education Fest \\
\hline 14 & $\begin{array}{l}\text { Visit to the Department of Biological Applications \& Technologies, University of } \\
\text { Ioannina, Greece }\end{array}$ \\
\hline \multirow[t]{3}{*}{15} & General rehearsal \\
\hline & School presentation \\
\hline & Evaluation (Post-questionnaire) \\
\hline
\end{tabular}


In one of these sessions (session 9) stories were used, since they can be appealing educational tools, as, apart from being amusing, they engage students in an authentic environment. Additionally, when knowledge is incorporated in a story, then it can be remembered more easily than in other way. Moreover, the association of knowledge with emotions enables it to easily pass to the long termmemory (Egan, 1989 as mentioned in Mavrikaki \& Kapsala, 2014).

It is worth mentioning that the textbook used for teaching biology in $9^{\text {th }}$ grade students in Greece includes amongst others a chapter on genetics, through which the students are taught basic concepts in genetics such as DNA, genes and alleles, chromosomes, DNA replication, gene expression, cell division, mendel's laws and mutations. However, unfortunately, in the greek education system $9^{\text {th }}$ grade students are taught biology only once a week. Hence, a program like the one we implemented offers the biology teacher the possibility to approach concepts that are not included in the school textbook, such as modes of inheritance, genetic diagnosis etc.

\section{Constructing the stories and the session material}

The 9th session included 5 stories. The stories were created following the steps suggested by Moitra (2014). These steps are summarized in Table 2. The most important step was determining the learning goals and objectives for each story.

Table 2. Summarising the steps for the creation of a story.

\begin{tabular}{ll}
\hline Step & Description \\
\hline Step 1 & Creating or obtaining an appropriate story \\
Step 2 & Determining learning goals and objectives \\
Step 3 & Building the narrative framework \\
Step 4 & Adding scientific/educational content \\
Step 5 & Adding visual content, links to resources and inquiry-based questions \\
Step 6 & Test-driving the narrative in the classroom \\
\hline
\end{tabular}

A worksheet was designed for each story. Each worksheet included the story and questions on the story. Stories 2 and 3 were based on stories found on the internet. Stories 4 and 5 were based on true stories. The questions were all designed by the authors. The worksheet for story 4 was digital, as it included a link to a scientific article, whereas the worksheets for stories 1, 2, 3 and 5 were in written form. The stories along with the learning goals and the questions for each story are given in Table 3 .

The worksheets were administered one at a time to the students, who were given time to read each story. Then, additional information was used to enable the students understand the scientific context behind the stories. The additional information was supplied either orally or visually by figures and pedigrees incorporated into powerpoint presentations. Afterwards the stories were discussed in class. The questions given in the worksheets were answered by the students in the discussion following the reading of each story with the exception of question 1 of story 5 , which was answered both before and after reading the story.

Table 3. The stories.

\begin{tabular}{|l|l|l|}
\hline \multicolumn{1}{|c|}{ Story 1 } & \multicolumn{1}{|c|}{ Learning goals } & \multicolumn{1}{c|}{ Questions } \\
\hline In a routine visit to the pediatrician the & 1. Get to know the & 1. Why is the 50\% of the sons who \\
doctor observes that Tasos, aged 4, has & basics of X-linked & are born to mothers-carriers of the \\
enlarged muscles in his legs, which is a & inheritance. & $\begin{array}{l}\text { Duchenne muscular dystrophy gene } \\
\text { possible indication of Duchenne }\end{array}$ \\
$\begin{array}{l}\text { muscular dystrophy, a syndrome that } \\
\text { causes paralysis and death from heart }\end{array}$ & $\begin{array}{l}\text { implications of } \\
\text { genetic diagnosis of }\end{array}$ & $\begin{array}{l}\text { 2. Why Tasos can't have inherited } \\
\text { the mutation from his father? }\end{array}$ \\
\hline
\end{tabular}




\begin{tabular}{|c|c|c|}
\hline $\begin{array}{l}\text { failure in the age of } 25 \text {. It is due to an } \\
\text { X-linked gene, which means that } 50 \% \\
\text { of the sons born to carrier mothers are } \\
\text { affected. The pediatrician asks his } \\
\text { parents whether he loses his } \\
\text { balance easily. Tasos' mother, } \\
\text { Elizabeth, replies that Tasos is } \\
\text { generally clumsy and usually } \\
\text { on the floor. The pediatrician suggests } \\
\text { genetic diagnosis, after the completion } \\
\text { of which it is verified that Tasos bears } \\
\text { the mutated gene on the X } \\
\text { chromosome. The doctor explains to } \\
\text { Elizabeth that she is the carrier of the } \\
\text { mutation and, hence, there is the } \\
\text { possibility that her } 7 \text {-year-old } \\
\text { daughter, Nikoleta, is also a carrier. } \\
\text { Elizabeth realizes that she inherited the } \\
\text { mutant allele from her mother, and, } \\
\text { thus, there is also a possibility that her } \\
\text { pregnant sister, Catherine, is also a } \\
\text { carrier. }\end{array}$ & $\begin{array}{l}\text { X-linked disorders } \\
\text { for other family } \\
\text { members. } \\
\text { 3. Get acquainted } \\
\text { with prenatal } \\
\text { diagnosis. }\end{array}$ & $\begin{array}{l}\text { 3. What is the risk of Nikoleta being } \\
\text { a carrier? } \\
\text { 4. Why Elizabeth can't have } \\
\text { inherited the mutation from her } \\
\text { father? } \\
\text { 5. Do you think that Elizabeth must } \\
\text { let her sister know? } \\
\text { 6. Do you think that Nikoleta must } \\
\text { tested? }\end{array}$ \\
\hline Story 2 & Learning goals & Questions \\
\hline $\begin{array}{l}\text { A. Maria, aged 20, biology student, is } \\
\text { engaged to Kostas, with whom they } \\
\text { have been together since they were } 14 \\
\text { years old. A few days ago Maria lost } \\
\text { her grandpa (from her mother's side), } \\
\text { who died of Huntington's disease at } \\
\text { the age of } 58 \text {. Huntington's is a disease } \\
\text { with an onset between } 35 \text { and } 44 \\
\text { years. It affects muscle coordination } \\
\text { and leads to cognitive deterioration } \\
\text { and dementia. Complications, such as } \\
\text { pneumonia and heart disease, reduce } \\
\text { life expectancy. There is no cure. It is } \\
\text { inherited in an autosomal dominant } \\
\text { fashion, which means that if someone } \\
\text { is affected, there is a } 50 \% \text { risk to } \\
\text { transmit the disease to one's offspring. } \\
\text { Therefore, Maria is thinking of having } \\
\text { a test to find out if she has inherited } \\
\text { the mutant gene in order to decide } \\
\text { whether she will invest time in her } \\
\text { university education or she will dumb } \\
\text { her studies and travel all around the } \\
\text { world, enjoying the years she has left. } \\
\text { Moreover, she is wondering whether } \\
\text { she should have children. Her mother, } \\
\text { Julia, aged } 37 \text {, opposes to her being } \\
\text { tested (Adapted from Zohar \& Nemet, }\end{array}$ & $\begin{array}{l}\text { 1. Get to know the } \\
\text { basics of autosomal } \\
\text { dominant } \\
\text { inheritance. } \\
\text { 2. Think of the } \\
\text { ethical implications } \\
\text { of presymptomatic } \\
\text { and prenatal } \\
\text { diagnosis for late- } \\
\text { onset disorders. } \\
\text { 3. Think of the } \\
\text { ethical implications } \\
\text { of third parties, such } \\
\text { as insurers, } \\
\text { employers and } \\
\text { lawyers, having } \\
\text { access to one's } \\
\text { genetic profile. } \\
4 \text {. Think of the } \\
\text { implications of } \\
\text { genetic diagnosis of } \\
\text { autosomal dominant } \\
\text { disorders for other } \\
\text { family members. }\end{array}$ & $\begin{array}{l}\text { 1. What is the possibility of Maria } \\
\text { being a carrier of the disease? } \\
\text { Explain. } \\
\text { 2. Why doesn't Julia want Maria to } \\
\text { be tested? } \\
\text { 3. Why does Maria want to be } \\
\text { tested? } \\
\text { 4. If Maria is a carrier of the } \\
\text { disease, what is her risk of } \\
\text { giving birth to an affected } \\
\text { child? } \\
\text { 5. What would you do if you were } \\
\text { in Maria's shoes? } \\
\text { 6. What would you advise your } \\
\text { fiancée to do if you were } \\
\text { Kostas? }\end{array}$ \\
\hline
\end{tabular}




\begin{tabular}{|c|c|c|}
\hline $\begin{array}{l}\text { 2002). } \\
\text { B. Maria is tested positive for the } \\
\text { mutation and breaks up with Kostas. } \\
\text { Her mother's brother, Vassilis, } 39 \\
\text { years old, father to two young } \\
\text { children, decides to be tested and he } \\
\text { as well is tested positive with the } \\
\text { mutation. When, after a few years, } \\
\text { Vassilis and his wife Eugenia get a } \\
\text { divorce, his ex-wife's lawyer plans to } \\
\text { use his test result in the trial for the } \\
\text { children's custody. } \\
\text { Maria's brother, Stavros, does not } \\
\text { want to be tested. However, his wife } \\
\text { Ismini is pregnant and she visits a } \\
\text { geneticist, as she decides to } \\
\text { perform genetic diagnosis for the } \\
\text { disease in order to have the option of } \\
\text { terminating the pregnancy in the case } \\
\text { of an affected embryo. When the } \\
\text { geneticist reminds her that a positive } \\
\text { result will mean that her husband - } \\
\text { who does not want to be tested - is } \\
\text { also an affected carrier, she replies that } \\
\text { not knowing fills her with lots of } \\
\text { stress that might endanger the fetus. }\end{array}$ & & $\begin{array}{l}\text { decision? } \\
\text { 4. What would you do if you were in } \\
\text { the geneticist's shoes? } \\
\text { 5. Do you think that Ismini should } \\
\text { perform the diagnosis? } \\
\text { 6. If Ismini performs the diagnosis, } \\
\text { what do you think she should do in } \\
\text { the case of an affected pregnancy? } \\
\text { 7. What would the implications of a } \\
\text { positive result be for Stavros' work } \\
\text { and insurance? }\end{array}$ \\
\hline Story 3 & Learning goals & Questions \\
\hline $\begin{array}{l}\text { Dimitris and Vassia want to have a } \\
\text { child and decide to get tested, since } \\
\text { Dimitris' sister, Dora, suffered with } \\
\text { cystic fibrosis, which is inherited in an } \\
\text { autosomal recessive model. Its main } \\
\text { characteristic is the production of a } \\
\text { thick mucus that blocks organs and } \\
\text { pores of the body, mainly the lungs and } \\
\text { the pancreas, causing lung infections } \\
\text { and pancreatic failure respectively } \\
\text { that gradually destroy the lungs and } \\
\text { lead to respiratory failure and death at } \\
\text { around the age of } 25 \text {. More than } 900 \\
\text { mutations have been found in } \\
\text { responsible gene, but lab techniques } \\
\text { cannot detect them all, in fact only } 85 \% \\
\text { of the carriers are being currently } \\
\text { detected. After the test, Dimitris and } \\
\text { Vassia were informed that Vassia was } \\
\text { carrying a mutant gene, even though } \\
\text { there was no history in her family, } \\
\text { whereas the result was negative for } \\
\text { Dimitris. The geneticist suggested that }\end{array}$ & $\begin{array}{l}\text { 1. Get to know the } \\
\text { basics of autosomal } \\
\text { recessive inheritance. } \\
\text { 2. Understanding the } \\
\text { significance of carrier } \\
\text { testing for } \\
\text { reproductive } \\
\text { decisions. } \\
\text { 3. Understanding the } \\
\text { implications } \\
\text { involved with the } \\
\text { genetic diagnosis of } \\
\text { diseases caused by } \\
\text { mutations that are } \\
\text { not always detected } \\
\text { in the lab. }\end{array}$ & $\begin{array}{l}\text { 1. Why doesn't Vassia suffer from } \\
\text { the disease? } \\
\text { 2. How many mutant genes must } \\
\text { Dora have? } \\
\text { 3. Why did the doctor suggest } \\
\text { that Dora should be tested? } \\
\text { 4. What was the possibility that } \\
\text { Dimitris was a carrier of the } \\
\text { mutant gene? } \\
\text { 5. Is Dimitris a carrier of the disease? } \\
\text { 6. What is the possibility of Dimitris } \\
\text { and Vassia having a child with } \\
\text { cystic fibrosis, if Dimitris is a. a } \\
\text { carrier b. not a carrier? }\end{array}$ \\
\hline
\end{tabular}




\begin{tabular}{|c|c|c|}
\hline $\begin{array}{l}\text { Dora should be tested. The test showed } \\
\text { that she carried a known mutation in } \\
\text { only one of the two genes. Based on } \\
\text { story on } \\
\text { http://www.pbs.org/inthebalance/ } \\
\text { archives/ourgenes/who_gets_to_know/ } \\
\text { who_read.html (accessed March 2020) }\end{array}$ & & \\
\hline Story 4 & Learning goals & Questions \\
\hline $\begin{array}{l}\text { Watch the video } \\
\text { https://www.youtube.com/watch? } \\
\text { v=ly7tS7k6ozM (accessed March 2020) } \\
\text { and answer the questions. }\end{array}$ & $\begin{array}{l}\text { Think of the uses and } \\
\text { implications of } \\
\text { predisposition } \\
\text { testing. }\end{array}$ & $\begin{array}{l}\text { 1. Why did Angelina Jolie have a } \\
\text { mastectomy; } \\
\text { 2. Would you do the same, if you } \\
\text { were in her shoes; or Would you } \\
\text { encourage your wife to do the same, } \\
\text { if you were Brad Pitt; }\end{array}$ \\
\hline Story 5 & Learning goals & Questions \\
\hline $\begin{array}{l}\text { Molly Nash was born on } 4^{\text {th }} \text { July } 1994 \\
\text { with Fanconi's anemia, a lethal genetic } \\
\text { disease, which is inherited in an } \\
\text { autosomal recessive fashion and } \\
\text { causes defects in the bone marrow and } \\
\text { ends up in leukaemia and other forms } \\
\text { of cancer. Her best chance of survival } \\
\text { was a bone marrow transplant from a } \\
\text { compatible sibling. Her parents Lisa } \\
\text { and Jack Nash wanted another child } \\
\text { very much, but they had decided to } \\
\text { abandon the idea, since there was a } \\
\text { possibility to give birth to another } \\
\text { child like Molly and the termination of } \\
\text { an affected pregnancy after prenatal } \\
\text { diagnosis was not an option for Mrs } \\
\text { Nash. Then, they found about } \\
\text { preimplantation genetic diagnosis } \\
\text { through which they could be able to } \\
\text { give birth to a child, which not only } \\
\text { would be healthy, but would also } \\
\text { serve as an absolutely compatible } \\
\text { bone marrow transplant donor. In } \\
\text { January } 1999 \text { Lisa Nash produced } 12 \\
\text { ovules, } 2 \text { healthy and compatible } \\
\text { embryos were found, she got pregnant } \\
\text { but she aborted. In June she produced } \\
4 \text { ovules, } 1 \text { healthy and compatible } \\
\text { embryo was found, but she did not get } \\
\text { pregnant. In September she produced } \\
8 \text { ovules, one healthy and compatible } \\
\text { embryo was found, but again she did } \\
\text { not get pregnant. In December she } \\
\text { produced } 24 \text { ovules, one compatible } \\
\text { and healthy embryo was found, she } \\
\text { got pregnant and Adam Nash was }\end{array}$ & $\begin{array}{l}\text { 1. Think of the uses } \\
\text { and implications of } \\
\text { preimplantation } \\
\text { genetic diagnosis for } \\
\text { genetic diseases. } \\
\text { 2. Think of the } \\
\text { implications } \\
\text { involved with } \\
\text { preimplantation } \\
\text { genetic diagnosis } \\
\text { aiming at the } \\
\text { selection of embryos } \\
\text { that are can serve as } \\
\text { bone marrow donors } \\
\text { for their siblings. }\end{array}$ & $\begin{array}{l}\text { 1.What do you think about using } \\
\text { preimplantation genetic } \\
\text { diagnosis with the intention of } \\
\text { giving birth to a child compatible } \\
\text { with his/her sibling who is suffering } \\
\text { from a lethal inherited form of } \\
\text { anemia so that his/her bone } \\
\text { marrow can be used for the } \\
\text { salvation of the sick child? } \\
\text { 2.What is the possibility of Lisa and } \\
\text { Jack Nash giving birth to another } \\
\text { child with the same problems as } \\
\text { Molly's? }\end{array}$ \\
\hline
\end{tabular}


born on 29 August 2000. After 2

months tissue from Adam's umbilical cord was transferred to Molly.

(Steinbock, 2009)

\section{Evaluation}

In the end of the session, each student was asked to write a short comment on the process. Some of the comments we received were "The stories were not only interesting, but also helped me learn a lot of things", "I very much liked this way of teaching", "I can't believe how quickly time passed by", "I learnt a lot in an amusing way", "It's amazing how a process that aims to teach as genetics can be so amusing".

Moreover, in the end of the program in May students were asked to complete evaluation questionnaires on the program. From Table 4, which shows the responses of the students to the question "Rate the following on a scale from 1 to 5 ", we deduce that the majority of the students rated the individual activities of the program as good or very good and they evaluated the program on the whole as good or very good. The stories/case studies were rated as good or very good by the $89.6 \%$ of the students.

Table 4. Responses of the students to the question "Rate the following on a scale from 1 to 5 (1=very bad, 2=bad, 3=average, 4=good, 5=very good, DK= I don't know).

\begin{tabular}{lrrrrrr}
\hline & 1 & 2 & 3 & 4 & 5 & DK \\
\hline Teleconference & $0 \%$ & $6.90 \%$ & $17.25 \%$ & $44.80 \%$ & $27.60 \%$ & $3.45 \%$ \\
Role-plays & $3.45 \%$ & $0 \%$ & $6.90 \%$ & $17.24 \%$ & $65.51 \%$ & $6.90 \%$ \\
Visit to the university & $0 \%$ & $0 \%$ & $3.40 \%$ & $13.80 \%$ & $75.90 \%$ & $6.90 \%$ \\
Stories/Case-studies & $0 \%$ & $0 \%$ & $6.90 \%$ & $37.90 \%$ & $51.70 \%$ & $3.50 \%$ \\
Film GATTACA & $0 \%$ & $3.40 \%$ & $6.90 \%$ & $34.50 \%$ & $55.20 \%$ & $0 \%$ \\
DNA isolation & $0 \%$ & $3.45 \%$ & $3.45 \%$ & $13.80 \%$ & $79.30 \%$ & $0 \%$ \\
Chromosome observation & $3.45 \%$ & $0 \%$ & $6.90 \%$ & $24.10 \%$ & $62.10 \%$ & $3.45 \%$ \\
Discussions & $0 \%$ & $6.90 \%$ & $3.40 \%$ & $34.50 \%$ & $55.20 \%$ & $0 \%$ \\
Overall evaluation & $0 \%$ & $0 \%$ & $10.35 \%$ & $20.68 \%$ & $65.52 \%$ & $3.45 \%$ \\
\hline
\end{tabular}

In addition to the above, from discussions with the students as well as their parents we came to the conclusion that the program on the whole and this session specifically motivated the students, it boosted their scientific literacy and contributed in the formation of a positive attitude of the students towards genetics.

\section{Discussion}

The students who participated in the program expressed themselves very positively about the stories/case studies used in the program, through which they got familiar with basic genetics, they acquired new knowledge on the applications and implications of genetic diagnosis in a pleasant way, they appreciated the use of genetics knowledge in everyday life and they learnt to transfer their knowledge of genetics to everyday problems. Furthermore, they were confronted with dilemmas, they developed argumentation abilities and learnt to respect each other's opinions.

On the whole, the impression we got after the implementation of the program was that even a subject with so many issues - ethical, social etc - can be approached, even with junior high school students, as long as the suitable activities are chosen. Moreover, as it was already mentioned, a program like that 
offers the biology teacher the opportunity to go beyond the school textbook and approach material that could not be covered in a school subject that is taught for one hour per week.

\section{Acknowledgments}

Special thanks to the biology teacher Niki Rose from St George's High School, Lakatameia, Cyprus for the title of our program.

\section{References}

Cockell, A. and Rodeck, C., (2001). Prenatal diagnosis. In: J.C. Harper, J.D.A. Delhanty, A. H. Handyside (Ed.), Preimplantation Genetic Diagnosis (pp. 27-44). Chichester: Wiley.

Decruyenaere, M., Evers-Kiebooms, G., Welkenhuysen, M., Bande-Knops, J., Van Gerven, V., Van den Berghe, H., (1995). Adolescents' opinions about genetic risk information, prenatal diagnosis and pregnancy termination. International Medical Genetics, 32, 799-804.

Driver, R., Newton, P., and Osborne, J., (2000). Establishing the norms of scientific argumentation in classrooms. Science Education, 84(3), 287-312.

Handyside, A.H. and Delhanty, J.D., (1997). Preimplantation genetic diagnosis: Strategies and surprises. Trends in Genetics, 13(7), 270-275.

Harper, J.C. and Delhanty, J.D., (2000). Preimplantation genetic diagnosis. Current Opinion in Obstetrics E Gynaecology, 12, 67-72.

Mavrikaki, E. and Kapsala, N., (2012). Teaching biology by storytelling. Proceedings of the $5^{\text {th }}$ International Conference, European Society for the History of Science, 612-617.

Moitra, K., (2014). Storytelling as an Active Learning Tool to Engage Students in a Genetics Classroom. Journal of Microbiology \& Biology Education, 15(2), 332-334.

National Research Council. (1996). National science education standards, Washington DC: National Academy Press.

Steinbock, B., Arras, J., and London, A.J., (2009). Ethical Issues in Modern Medicine: Contemporary Readings in Bioethics. Boston: McGraw Hill.

Zohar, A. and Nemet, F., (2002). Fostering Students' Knowledge and Argumentation Skills through Dilemmas in Human Genetics. Journal of Research in Science Teaching, 39(1), 35-62. 